This item was submitted to Loughborough's Research Repository by the author.

Items in Figshare are protected by copyright, with all rights reserved, unless otherwise indicated.

\title{
How to be a contact zone: the missionary Karl Gützlaff between nationalism, transnationalism and transculturalism, 1827-1851
}

PLEASE CITE THE PUBLISHED VERSION

http://www.v-r.de/en/european_missions_in_contact_zones/t-2/1035635/

\section{PUBLISHER}

Vandenhoeck \& Ruprecht

VERSION

AM (Accepted Manuscript)

\section{PUBLISHER STATEMENT}

This work is made available according to the conditions of the Creative Commons Attribution-NonCommercialNoDerivatives 4.0 International (CC BY-NC-ND 4.0) licence. Full details of this licence are available at: https://creativecommons.org/licenses/by-nc-nd/4.0/

\section{LICENCE}

CC BY-NC-ND 4.0

\section{REPOSITORY RECORD}

Klein, Thoralf. 2019. "How to Be a Contact Zone: The Missionary Karl Gützlaff Between Nationalism, Transnationalism and Transculturalism, 1827-1851". figshare. https://hdl.handle.net/2134/18126. 
How to be a Contact Zone: The Missionary Karl Gützlaff between Nationalism, Transnationalism and Transculturalism, 1827-1851

\section{Thoralf Klein}

In the work of Mary Louise Pratt, the contact zone is defined as a liminal space where crosscultural interaction takes place. ${ }^{1}$ Obviously, this interaction does not imply an equal footing; on the contrary, such processes are governed by inequalities and hierarchies of power. Pratt herself defined the concept rather loosely, which is sometimes seen as an advantage, as it »does not presuppose the existence of any rigid, inflexible cultural boundaries. It enables us to see mingling, interaction, accommodation, hybridisation and confluence as well as conflicts across borders of many kinds. ${ }^{2}$ Still, her understanding of cultural interaction is not unproblematic. Pratt conceives of the contact zone as a constellation enabling the »spatial and temporal copresence of subjects previously separated by geographic and historical disjunctures, and whose trajectories now intersect. ${ }^{3}$ Accordingly, she privileges direct interaction, for example in describing how a course she taught became a contact zone in which members of different ethnic groups shared their backgrounds and perspectives. ${ }^{4}$ Importantly, although Pratt mostly analyses travel writings - i.e. texts addressing a metropolitan audience -, she apparently understands them as products of the contact zone rather than as agents of cultural interaction and transformation in their own right. ${ }^{5}$ This also implies a distinction between the contact zone, where the original interaction takes place, on the one hand and the writing and, more broadly speaking, communication about this interaction on the other.

In other words, the contact zone is a rather narrow concept. As a consequence, the complex and dialectical processes of cultural flows between colonies and metropoles, between an increasingly hegemonic and domineering Europe and North America and the non-»Western « world, tend to be limited to tangible forms of interaction within a clearly demarcated if

\footnotetext{
${ }^{1}$ Mary Louise PRATT, Imperial Eyes. Travel Writing and Transculturation, London 1992; id., Art of the Contact Zone, in: Profession (1991), pp. 33-40.

${ }^{2}$ Monika GÄNSSBAUER, »In China They Eat the Moon«: Western Images of China from the 19th to the 21st Century, in: Asien 121 (2011), pp. 119-129, at p. 126.

${ }^{3}$ PRATT, Imperial Eyes, p. 7.

${ }^{4}$ Id., Art of the Contact Zone, pp. 39-40.

${ }^{5}$ Ibid., p. 36, referring to the First New Chronicle and Good Government by Felipe GUAMAN POMA DE AYALA, a seventeenth-century text, which she analyses in great detail and whose impact she compares with Garcilaso DE LA VEGA's Royal Commentaries of the Incas.
} 
permeable spatio-temporal constellation. In the present essay, I attempt to broaden this perspective. My fundamental assumption is that in looking at processes of cultural interaction, we need to shift our attention beyond a narrowly defined contact zone to take global communication flows into account. Owing to the acceleration of communication that began as early as the Age of Sail, the sites of interaction between Europeans and non-Europeans were not limited to readily discernible spaces and situations of physical »copresence«; rather, they were enmeshed into an ever-tightening global network of media and information exchange. In bringing a broader perspective to bear, I do not mean to deny that the interactions described by Pratt are important and meaningful. However, as a result of the approach taken in this essay, the contact zone will merge into a multi-layered web of communication. This comprises face-to-face interaction as well as the variegated »mediascapes « - if this term may be appropriated here ${ }^{6}$ - and the infrastructural processes (shipping, railways, telegraphy and others) underpinning the latter. It also includes the tensions arising from the unavoidable practice of translation.

The necessity of translation from one culture to another (or, indeed, several others) is, again, left vague in Pratt's work. But it is crucial to an adequate understanding of cross-cultural or transcultural processes and interactions, and it involves far more than just the linguistic dimension. As Nancy Hagedorn has written: »When interpreters translated and explained disparate languages and rituals infused with cultural meanings and values, they acted as brokers, mediating the confrontation of European and non-European cultures. « ${ }^{7}$ Cultural brokerage in this sense depends crucially on the knowledge of languages, but also on a sensitivity for different sets of cultural symbols and practices. Taken together, they form the communicative expertise on which all cultural brokerage rests. ${ }^{8}$ In a sense, then, the cultural broker can be called a »contact zone« in their own right, as in their very person at least two cultures become copresent. The ways in which this happens can vary: As a rule they will have

\footnotetext{
${ }^{6}$ Arjun AppadurAI, Disjuncture and Difference in the Global Cultural Economy, in: Theory, Culture and Society 7 (1990), pp. 295-310, at pp. 298-299. The term refers to the »increasing distribution of the electronic capabilities to produce and disseminate information«, which explicitly includes both digital, visual and print media, as well as the images produced by such media. Ibid., mediascapes are equally defined as »image-centred, narrative-based accounts of strips of reality«.

${ }^{7}$ Nancy L. HAGEDORN, Brokers of Understanding: Interpreters as Agents of Cultural Exchange in Colonial New York, in: New York History 76 (1995), pp. 379-408, at p. 380. I have taken the liberty of replacing »Indian« with »non-European«, as the statement has value beyond its immediate historical context.

${ }^{8} \mathrm{I}$ am drawing here on ideas previously formulated in Thoralf KLEIN / Reinhard ZÖLLNER, Einleitung: Karl Gützlaff als Kulturvermittler, in: id. (eds.), Karl Gützlaff (1803-1851) und das Christentum in Ostasien. Ein Missionar zwischen den Kulturen, Nettetal 2005, pp. 3-20, at p. 4. See also Nancy L. HAGEDORN, »A Friend to go between Them«: The Interpreter as Cultural Broker during Anglo-Iroquois councils, 1740-70, in: Ethnohistory 35 (1988), 40-60.
} 
been socialised into one culture, while they may acquire expertise in other cultures through socialisation or through more conscious and analytical modes of learning. As a consequence, it cannot be taken for granted that cultural brokers are equally well versed in all cultures they are familiar with. Distortions in the translation process may result from this hierarchy of cultural expertise, from the self-interest of the broker, or from their interactions with the groups they are mediating between. ${ }^{9}$ It should be pointed out that such mediation does not necessarily involve face-to-face interaction, but can also take the form of long-distance communication and hence the use of what we commonly refer to as media.

Although media tend to have a life of their own that is determined by their underlying technological potential, they are nonetheless intimately linked with human action. Humans operate and use media technologies; conversely, media structure the scope, speed and depth of interpersonal communication. This is true anywhere at any time, but it especially comes to the fore where changes in media technology, broadly understood, enable new forms or an intensification of communication. Such a change occurred in the late eighteenth and early nineteenth centuries, beginning with the increasing regularity of shipping and mail services, and it did not leave Christian missionaries unaffected. Indeed, one might say that the global scale that Christian missions took on in the nineteenth century was predicated on the ability to communicate effectively across long distances. Where missionaries evangelising overseas were part of a mission organisation, they became increasingly answerable to a home board (which became, in a sense, a remote participant in the contact zone) and/or connected them to the mission's supporting circles for purposes of fundraising. Where they were free missionaries lacking or deliberately foregoing an organisational prop, they were able to build up a network buttressing their activities. And missionary strategy relied not only on face-toface interaction, but equally on the written word, both of which involved processes of translation in the broadest sense of the term. ${ }^{10}$ Knowledge dissemination, in particular through translation, could again occur on a global scale. The idea of a limited contact zone (and really it only makes sense as a limited space; there is no point in positing a contact zone that equals the whole world) needs to be supplemented by reconstructing global communication flows.

\footnotetext{
${ }^{9}$ For the self-interest of the cultural broker see the typology developed in Robert PAINE, A Theory of Patronage and Brokerage, in: id. (ed.), Patrons and Brokers in the East Arctic, St. John's, NL 1971, pp. 8-21. For the reinterpretation and appropriation of the translated message by a target group see Birgit MEYER, Translating the Devil. Religion and Modernity among the Ewe in Ghana, Edinburgh 1999.

${ }^{10}$ I am thinking here, among others, of the classic study by Lamin SANNEH, Translating the Message. The Missionary Impact on Culture, Maryknoll, NY 1989.
} 
This article is focused on an early China missionary who established himself as a cultural broker and a hub of communication between China/(East) Asia and Europe as well as North America: the German missionary Karl Friedrich August Gützlaff (1803-1851). Gützlaff can be described as a product of the contact zone, as he spent most of his adult life in Southeast and subsequently East Asia, and only thus became a public figure. But a quick glance at his multifarious activities as a freelance missionary, explorer, pamphleteer and propagandist, linguistic prodigy and translator, interpreter and self-made scholar, colonial official and spymaster, reveals something else: To begin with, no neat distinction is possible between his activities on the spot (in the contact zone) and his writings, as the latter were themselves vehicles of transcultural mediation. And as a consequence, the scope of his cultural brokerage between West and East was not limited. Beyond a copresence of various groups in the contact zone, what we see is a mediatised communication on a global scale transmitting knowledge and information from East Asia to the various countries of Europe and the United States and vice versa. And this communication flow was without doubt accompanied by flows of funds, about which we know little as yet, but which are of vital importance.

The above is indeed confirmed by Gützlaff's very persona, as his identity became the site of a playful transcultural ambiguity: he was born Karl Friedrich August Gützlaff in the Eastern German region of Pomerania, but came to be known in the English-speaking world as Charles Gutzlaff. All of his three wives were English, and the list of his publications contains more English titles than German. And indeed his Anglicisation was not without repercussions: in 1837, an early admirer of Gützlaff's had his son baptised Charles Gutzlaff Hildreth, and upon the little boy's untimely death three years later made a donation to support Gützlaff's distribution of Christian tracts in China. ${ }^{11}$ Even more importantly, Gützlaff styled himself Guo Shili (sometimes also Guo Shila) in his dealings with the Chinese and took obvious pride in his »adoption « into the Guo lineage of Tong'an in the southwestern Chinese province of Fujian. ${ }^{12}$ Other Chinese names he adopted were "Gaihan« or Aihanzhe (which can be translated as »the China lover«), which he used in his Chinese-language publications until 1836 and in his correspondence with Christian supporters in Germany in the 1840s. His contributions to the Chinese Repository, an English-language periodical published in Canton

\footnotetext{
${ }^{11}$ Jessie Gregory LuTZ, Opening China. Karl F. A. Gützlaff and Sino-Western Relations, 1827-1852, Grand Rapids, MI 2008, p. 128.

${ }^{12}$ Patrick HanAN, The Missionary Novels of Nineteenth-Century China, in: Harvard Journal of Asiatic Studies 60 (2000), pp. 413-443, at p. 420. See also Gaïhan’s (Carl Gützlaff's) Chinesische Berichte, von der Mitte des Jahres 1841 bis zum Schluß des Jahres 1846, Kassel 1850, p. 170: „Several captains were my relatives and were sincerely happy to see me again. « Gützlaff employed several versions for writing his adopted name in Chinese characters.
} 
(Guangzhou) in southern China between 1832 and 1851, were often signed »Philosinensis«, a Greek-Latin translation of the same name. In his writings in Chinese after 1836, Gützlaff adopted a new alias, Shande (»supreme virtue «). ${ }^{13}$ Gützlaff's plays with transcultural identities even extended to his physical appearance, as in a conscious display of crossdressing, he seems occasionally to have dressed in Chinese garb, for example in the famous painting by George Chinnery. This portrait, probably the best-known likeness of Gützlaff, was directed at a »Western« audience, underscoring Gützlaff's immersion into Chinese culture and by extension his expertise on all things Chinese. On the other hand, Chinese memory of the man has not accepted his sinophilic attitude as sincere, and Gützlaff - with some justification - is still rejected as a champion of »Western « imperialism. ${ }^{14}$

Establishing himself at the hub of a global exchange network, Gützlaff's role as a broker between different groups took on different forms. Much of his exchange with audiences in Europe and North America is best described as transnational, in the sense that Gützlaff was aware of national peculiarities, but emphasised a shared Christian (or more narrowly Protestant) culture as well as the common political interests of the »Western « states in East Asia. During the 1840s, his strategies were more strongly influenced by his German national identity as well as his Prussian citizenship; finally, as an intermediary between »Western « and East Asian cultures, he had grown into a transcultural figure by the early 1830s. In the following, I will analyse these different aspects separately.

Gützlaff's transnational career, 1820-1842

With its national, transnational and transcultural dimensions, Gützlaff's career was the result of both circumstances beyond his control as well as of conscious decisions he took. To begin with the former: Gützlaff's talents were discovered by the Prussian King, Friedrich Wilhelm III (reigned 1797-1840), on the occasion of a visit to the former's hometown of Pyritz (now Pyrzyce, Poland). The King arranged for Gützlaff to receive training as a missionary at Johannes Jänicke’s (1748-1827) mission school in Berlin. In the emerging transnational missionary movement, Jänicke cut an interesting figure. Although he spent his entire life in

\footnotetext{
${ }^{13}$ LuTZ, Opening China, pp. 335-336.

${ }^{14}$ See, for example, Yan WANG, Review of Thoralf Klein / Reinhard Zöllner, Karl Gützlaff und das Christentum in Ostasien. Ein Missionar zwischen den Kulturen, in: Jahrbuch für europäische Überseegeschichte, pp. 355357, at p. 357: »For Chinese people it is not easy to place Gützlaff's unscrupulous activity and ambition in the shadow of a cultural broker.«
} 
Berlin, he was descended from a family of Bohemian refugees and preached in Czech as well as in German. ${ }^{15}$ More importantly for Gützlaff, he was in touch with mission societies in other countries. In the 1820s, German mission societies focused not on evangelising, but on educating and training missionaries to meet the rising need for manpower in mission organisations abroad. The course at Jänicke's school included languages and mathematics, but was neither systematic nor geared towards the practical needs of evangelising work. Upon Gützlaff's graduation, Jänicke arranged for his transfer to the Netherlands Mission Society (Nederlands Zendeling Genootschap, NZG) at Rotterdam, where he received a more comprehensive and practical training, e.g. in medicine. Still, as a scholar Gützlaff was mainly a self-made man. In 1827, he was dispatched to Dutch East India (today’s Indonesia), but in 1828 made up his mind to move to Bangkok and in 1831, he settled in the Portuguese colony of Macao on the Chinese coast. Gützlaff's strategy of focusing on evangelising among the Chinese was not approved by his superiors in Rotterdam, so despite holding on to his ties with the NZG for a while, Gützlaff had to all intents and purposes become an independent missionary.

This was a momentous decision. Gützlaff made use of his newly won freedom to embark on a flurry of activity. Christianity had been outlawed in China (or more precisely: the Qing Empire) since 1724, and in the 1830s the pioneers of Protestant missions, including Gützlaff, were busy searching for a foothold in the vast realm. This made them, as it were, natural allies of the »Western« merchants, who were basically trying to do the same in their attempt to circumvent the trade restrictions imposed on them by the Qing government. It is perhaps not surprising that Gützlaff was involved in a number of voyages along the Chinese coast and into other parts of East Asia. His most momentous trip, as ship’s surgeon and interpreter on the British ship Lord Amherst between February and September 1832, took him along the Chinese coast as far north as Manchuria, thence into Korean waters and finally to the island of Okinawa, at the time part of the nominally independent kingdom of Ryūkyū, a tributary state of the Qing Empire. In attempting to wrest trading privileges from local officials through a mixture of bluff and persuasion (and to distribute Christian tracts in passing), the mission was hardly successful, however. In the long run, the perceived intransigence of the Chinese

\footnotetext{
${ }^{15}$ Karl Friedrich LEDDERHOSE, Johann Jänicke, der evangelisch-lutherische Prediger an der böhmischen oder Bethlehems-Kirche zu Berlin, Berlin 1863, pp. 44-45. Interestingly, as made explicit ibid., p. x, the proceeds from this book were dedicated to the foundling hospital in Hong Kong, which »owes its existence to Dr. Gützlaff, who in the meanwhile has been blessed and perfected and who was a spiritual son of the blessed father Jänicke.«
} 
officials stiffened the resolve of the merchants to »open « China at all cost, if necessary through war. ${ }^{16}$

In the following years, Gützlaff became involved with British opium smugglers like James Matheson (1796-1878) and William Jardine (1784-1843). In his writings, the German missionary was very apologetic about his participation and as well as distancing himself from the opium business, asserted that he had been unable to stop it, as he had taken part in the voyages as only a guest. ${ }^{17}$ This claim, however, was disingenuous, as Gützlaff was again serving as interpreter, thus assuming a vital role in the transactions. In 1834 and 1835, he took part in two exploratory journeys to acquire tea seeds on behalf of an Indian-based tea company. At least the first of the two trips not only succeeded in obtaining the required specimens but also in hiring Chinese workers to process the tea leaves in India. ${ }^{18}$ Unfortunately, the cultivation of tea plants imported from China proved a failure and attention turned to the cultivation of the native variety. ${ }^{19}$

Besides his alliance with merchants, Gützlaff looked for other sources of financial support for his evangelistic activities. Through his first wife (who died in childbirth two years into their marriage), he had become personally wealthy. Still, he needed additional funds and thus in 1834 accepted the post as Secretary to the British Superintendent of Trade in Canton, thus becoming more formally involved with British political and commercial interests in China. None of these were sufficient to fund Gützlaff's mission work, however. It was for fundraising purposes, then, that the free missionary built up a transnational network of supporters including both individuals and institutions (for example, Bible, tract and mission societies) in the 1830s and 1840s. This network extended from North America to the UK, Germany, the Netherlands and Scandinavia and its success was in large measure determined by Gützlaff's ability to speak to the current national mood in each country - in many of his publications as well as his private writings, the anglophile Gützlaff stressed the unprecedented contribution of the British to the advancement of humanity and Christianity. But he equally

\footnotetext{
${ }^{16}$ Robert BICKERS, The Scramble for China. Foreign Devils in the Qing Empire, London 2011, pp. 69-75; for the context see ibid., pp. 18-50.

17 Gützlaff to Church Missionary Society, Macau 13 October 1835, quoted in Gerhard TIEDEMANN, Missionarischer Einzelgänger oder Visionär? Die Missionsmethoden Gützlaffs, in: KLEIN / ZÖLLNER (eds.), Karl Gützlaff und das Christentum in Ostasien. Ein Missionar zwischen den Kulturen, Nettetal 2005, pp. 193-231, at p. 203.

${ }^{18}$ Expedition to the Tea-District of Fŭh-këen, in: The Asiatic Journal and Monthly Register for British and Foreign India, China and Australasia 20 (1836), pp. 130-137. Cf. also LUTZ, Opening China, pp. 83-85.

${ }^{19}$ Helen SABERI, Tea. A Global History, London 2010, pp. 126-131.
} 
appealed to the enterprising and pioneering spirit of Jacksonian America and warned the Germans - then still a long way from unification - that they ought not to fall behind in their support for evangelisation. ${ }^{20}$ Communication was vital to the effort and occurred at various levels: The most personal form was direct correspondence, but letters could reach a wider audience when published, a strategy to which Gützlaff occasionally resorted. Most importantly, his correspondence with Christian Gottlob Barth (1799-1862), a pivotal figure in south-west German mission circles and one of Gützlaff's most vocal supporters, went into print in Germany in 1850, covering the years 1841 to 1846 and filling an entire volume. ${ }^{21}$

Published letters formed part of the second form of communication, which consisted of short articles, extracts from his diaries and travel reports and opinion pieces appearing in papers and periodicals associated with missions and churches, but also in secular publications, especially in Germany. ${ }^{22}$ The third level consisted of book-length volumes, such as his travelogue of the voyage with the Lord Amherst published in 1833, his Sketch of Chinese History, which followed a year later, and most notably his China Opened, which appeared in 1838. In all of his writings, Gützlaff forcefully supported the union of what has been called the three C's: Christianity, commerce and civilisation. In China Opened, he argued that China was not in fact a closed country (thought it might have seemed so from a European perspective), but in fact was opened at least to »Christian heroes and martyrs «. At the same time, he suggested that it might be possible to establish mutually beneficial relations with the Qing Empire if only some Westerners would take the trouble to explain to the Chinese the benefits of free trade. This is interesting in view of his own failures to convince Chinese officials of these benefits. ${ }^{23}$ What Opening China seems to suggest is that imparting »Western« knowledge - by which term Gützlaff understood both the Christian religion and the achievements of science - was a solution leading out of the impasse and would help realise China’s potential for »becoming one of the first nations in the world «. ${ }^{24}$ This idea was coupled with a rather condescending attitude towards China: once on a par with or even

\footnotetext{
${ }^{20}$ Jessie G. LUTZ / Rolland R. LUTZ, Karl Gützlaff as Propagandist and Fundraiser. Some Comparisons of Appeals and Sources of Support, in: KLEIN / ZöLlner (eds.), Karl Gützlaff und das Christentum in Ostasien, pp. 105-139. For Gützlaff's praise of Britain, cf. Charles GuTZLAFF, A Sketch of Chinese History, Ancient and Modern: Comprising a Retrospect of the Foreign Intercourse with China, vol. 2, London 1834, p. 291.

${ }^{21}$ Gaïhan's Chinesische Berichte.

${ }^{22}$ Lutz / Lutz, Karl Gützlaff as Propagandist and Fundraiser, pp. 111-125.

${ }^{23}$ On his second voyage in 1832, Gützlaff had carried a Chinese translation of a pamphlet by Charles Marjoribanks (1794-1833), president of the Select Committee of the EIC and an MP at Westminster, entitled »A brief account of the people and affairs of the great English nation « (Da Yingjili liguo renpin guoshi lüeshuo) and translated into Chinese by the first Protestant missionary in China, Robert Morrison (1782-1834). Cf. LUTZ, Opening China, pp. 185-186. As we have seen, the text failed to persuade Chinese officials.

${ }^{24}$ GUTZLAFF, China Opened, vol. 2, p. 181.
} 
superior to Europe, it had meanwhile fallen far behind, as the Europeans' "spirit of improvement « had the latter the »umpires of the world «. ${ }^{25}$

However, rather than simmering down, tensions between the Qing and the British Empires came to a head in the late 1830s. And given Gützlaff's preferences, it is not surprising to find him involved in the British military effort during the First Opium War (1839-1842), when he ran a spy network, providing the British troops with military intelligence. In particular his information concerning the navigability of rivers was vital to the British campaign. ${ }^{26}$ Gützlaff also was entrusted with administrative duties in conquered port cities: first as magistrate in Dinghai, principal town of the Zhoushan archipelago off the Chinese coast, in late 1840; from October 1841 to May 1842 in Ningbo and then briefly in Zhenjiang on the Yangzi River, before returning to his post at Dinghai in September 1842. He was recalled to Hong Kong in the summer of $1843 .{ }^{27}$ A scholar from Ningbo named Xu Shidong has left us a satirical poem providing a rather unflattering description of Gützlaff's tenure. Xu made a mockery of Gützlaff's communication with the Chinese: his boastful display of his linguistic skills, his ignorance, his arbitrary dispensation of justice (which, contrary to Chinese custom, was not documented in writing) and his public justification of the war and the opium trade. ${ }^{28}$ On the other hand, Gützlaff appears to have been sufficiently trusted by both sides to serve as interpreter at the peace negotiations at Nanjing in late August 1842 - although he was mostly doing routine jobs rather than translating diplomatic communication into Chinese. In his correspondence with Barth, he emphatically declared that he abhorred the war, yet justified it by pointing to God's higher purpose and the potential benefits to the missionary cause. ${ }^{29}$

In his career up to the First Opium War, Gützlaff appears as a genuinely transnational figure, setting out in the service of a Dutch missionary society, subsequently allying himself with British interests in China and creating a basis for his mission efforts that stretched from the US to Western and Northern Europe. Situated in East Asia, Gützlaff became the centre of a network that integrated East Asia into a global communication flow. After the war, Gützlaff

\footnotetext{
${ }^{25}$ Ibid.

${ }^{26}$ John OuChTERLOnY, The Chinese War. An Account of All the Operations of the British Forces From the Commencement To the Treaty of Nanking, London 1844, pp. 48-49, 224-230, 248-249.

${ }^{27}$ LuTZ, Opening China, p. 103; for Gützlaff's recall see also Qiying to Pottinger, Daoguang 23/09/16 = 19 October 1843, in: Thomas Francis WADE (ed.), Wên-chien Tzŭ-erh Chi. A Series of Papers Selected as Specimens of Documentary Chinese Designed to Assist Students of the Language as Written by the Officials of China, Shanghai 1909, vol. 1, p. 4.

${ }^{28}$ AYING (ed.), Yapian zhanzheng wenxueji, Beijing 1957, p. 24. An English translation is in Arthur WALEY, The Opium War Through Chinese Eyes, Stanford, CA 1958, pp. 230-231.

${ }^{29}$ Gaïhan’s chinesische Berichte, pp. 3-11.
} 
retained his attitude; it was the situation around him that changed and necessitated new responses.

Gützlaff's hesitant honeymoon with nationalism, 1842-1850

After the Opium War, Gützlaff continued to pursue both his secular and evangelistic activities. To begin with the former: in 1843 he was appointed Chinese Secretary to the government of the newly founded British crown colony of Hong Kong. In this capacity, he used his contacts to help non-British nationals to maintain their interests in China where possible. This included the attempts of Prussia and other German states to play a more active (if still marginal) role in China, now that the first of the so-called »unequal treaties « had loosened the strict Chinese trade regulations. Gützlaff gave active support to German efforts to explore the potential for trade and diplomatic relations. ${ }^{30}$ From the letters of the German merchant Richard von Carlowitz (1817-1886), who became the first Prussian and Saxon consul in China, we know that he relied on Gützlaff's advice and contacts with the Prussian government (Gützlaff was a Prussian subject and seems to have had no ties with the Saxon government) and with high-ranking Chinese officials such as the Manchu Qiying (17871858). ${ }^{31}$ From the same cache of letters we also know, on the other hand, that Gützlaff helped the Danish and Swedish commissioners to obtain the formal recognition of the Chinese officials, probably at Guangzhou (Canton). ${ }^{32}$ Gützlaff’s transnational outlook probably had not changed very much.

In Gützlaff's missionary efforts, however, Germany assumed a more important role than before the Opium War. This was partly down to the Pomeranian missionary's preferences, partly to the changing structure of Protestant missions in China. In the pre-war period, only a handful of pioneer missionaries had been active on the China coast. For this reason, Gützlaff had not found it very difficult to obtain funds from Anglo-American mission societies. After the war, however, these became directly involved in mission work in China, so funds became increasingly scarce and competition grew. ${ }^{33}$ Gützlaff's first attempt in 1839 to get two of the biggest German mission societies, the Basel and Rhenish Missions, interested in China was

\footnotetext{
${ }^{30}$ Elisabeth GRUBE, Friedrich Wilhelm Grube und seine Reise nach Indien und China, Krefeld 1848, p. 136 and passim.

31 Briefe Richards von Carlowitz aus Ostindien und China von 1844 an, unpublished typescript, private collection of the author, pp. 55-96.

${ }^{32}$ Ibid., p. 101.

${ }^{33}$ LUTZ / LUTZ, Karl Gützlaff as Propagandist and Fundraiser, pp. 129-131.
} 
perhaps accidental: a Basel missionary stationed in India had visited Gützlaff in Macau the previous year. At this point, nothing came of his efforts and he did not pursue the matter any further.

By the mid-1840s, the situation had changed considerably. In 1844, Gützlaff founded the Chinese Union in Hong Kong, which became an agency for training Chinese as evangelists. Having his hands full with his government job but eager to convert all of China to Christianity in the shortest possible time, Gützlaff had resorted to a new strategy: Not without reason, he was convinced that Chinese preachers would be cheaper and more effective than »Western « ones. But he was paternalistic enough to assume that some form of European oversight was indispensable. This time, Gützlaff managed to persuade the societies in Basel and Barmen to dispatch two missionaries each to China. His relationship with the new arrivals soon became strained, however, as Gützlaff favoured extensive evangelisation, while the four missionaries were more intent on intensive mission work through congregations. Both parties soon went their separate ways. $^{34}$

At about the same time, Gützlaff also became involved with attempts to found a common German Protestant mission to China. The originator and driving force behind this enterprise was a jurist named Christian Friedrich Elvers (1797-1862), President of the Court of Appeals at Kassel and a member of the directorial board of the Mission Society of Electoral Hesse. His initiative led to the founding of the German-Chinese Foundation in late 1846. Unfortunately, the new organisation suffered from a birth defect: Elvers had insisted that it be based on the Augsburg Confession, in other words: on Lutheran doctrine. Such narrow-minded confessionalism ran counter to the ideals of most German mission societies and led to the foundering of the organisation. ${ }^{35}$

Undeterred, Elvers changed his strategy and directed the foundation towards support of Gützlaff's Chinese Union. It was probably at Gützlaff's suggestion that the term »German« was dropped from the name of Elvers' foundation, and the newly constituted Chinese Foundation now became a general agency of sorts for Gützlaff's interests in Europe. It thus

\footnotetext{
${ }^{34}$ LuTZ, Opening China, pp. 220-228; Thoralf KLEIN, Die Basler Mission in der Provinz Guangdong (Südchina) 1859-1931. Akkulturationsprozesse und kulturelle Grenzziehungen zwischen Missionaren, chinesischen Christen und lokaler Gesellschaft, München 2002, pp. 16-17.

${ }^{35}$ Patrick DrEHER, Eine gemeinsame deutsche Mission für China? Die chinesische Stiftung und Gützlaff, in: KLEIN / ZÖLLNER (eds.), Karl Gützlaff und das Christentum in Ostasien, pp. 141-153, at pp. 142-146.
} 
inherited the role that Barth had played up to this point, and indeed in 1847, Gützlaff officially transferred the responsibility for his home base from Barth to the Chinese Foundation. ${ }^{36}$ The Foundation's principles paralleled those Gützlaff had envisioned for his Chinese Union: German leadership for a transnational and (indeed transcultural) enterprise.

When the new organisation began to totter again in the late 1840s, Gützlaff thought it was time to change his style of communication: Instead of relying on correspondence, he would personally advertise his cause. From January to November 1850 - in less than a year - he travelled almost the whole of Europe. It is easier to list the countries he did not include in this Grand Tour: Norway, Spain, Portugal and the Ottoman Empire. In other words, the Protestant missionary also visited predominantly Catholic countries. ${ }^{37}$ Gützlaff's advertising strategy was meticulously planned and executed, as his visit to the provincial town of Erfurt shows: Before, during and after his short visit (which lasted less than twelve hours), the local newspaper published articles on Gützlaff, no doubt placed by himself. ${ }^{38}$ And the marketing was successful: in Germany alone, about 100 associations were formed in support of Gützlaff, and more than a few people volunteered to become missionaries in China. The Chinese Foundation had already found a suitable candidate, a man named Carl Vogel (1825-1873), who arrived in China while Gützlaff was still in Europe. Unfortunately for the Foundation, Vogel soon became a critic of the organisation, which he eventually fell out with and left or by his own account - was expelled from. Confessional issues again played a role: Vogel was a member of the Reformed Church, but the Foundation insisted on ordaining him as a Lutheran. $^{39}$

More trouble lay ahead for Gützlaff. While he was still in Europe, missionaries in Hong Kong launched an enquiry into conditions in the Chinese Union and found that most of Gützlaff's Chinese evangelists were frauds who had not undertaken the extensive evangelisation tours they claimed to have made. Upon his return, Gützlaff sought to counter with an enquiry of its own, but the damage that had been done was beyond recall. Gützlaff lost his most important

\footnotetext{
${ }^{36}$ Ibid., pp. 146-147.

${ }^{37}$ LUTZ, Opening China, p. 229.

${ }^{38}$ Erfurter Zeitung, 4, 15 and 17 October 1850, in: KLEIN / ZÖLLNER (eds.), Karl Gützlaff und das Christentum in Ostasien, pp. 314-315 and pp. 332-335. See also Sylvia BRÄSEL, Missionar aus Überzeugung, Entdecker mit Marketingtalent. Gützlaff - der erste Deutsche in Korea, in: ibid., pp. 61-75, at pp. 73-74.

${ }^{39}$ Carl VogEL, Beiträge zur Geschichte der chinesischen Stiftung in Kurhessen und der Gützlaff'schen Mission in China, Frankfurt 1853, pp. 1-14; F. W. WINKEL, Correspondenz. Confessionelles aus Kurhessen, in: Monatsschrift für die evangelische Kirche in der Rheinprovinz und Westphalens nos. 4-5 (1853), pp. 238-250, at pp. 245-246; LUTZ, Opening China, pp. 233-234; for Gützlaff's supporters see DREHER, Eine gemeinsame deutsche Mission, p. 149.
} 
supporters, and his death on 9 August 1851, in the midst of the turmoil, deprived the Chinese Union of its main prop. Under Gützlaff's successor, the missionary Robert Neumann (18231890), the Union dissolved a few years later.

Gützlaff's outlook did not substantially change in his later years. He was not converted to the cause of Protestant German nationalism as championed by Elvers. On the other hand, he began to rely on Europe and specifically on Germany more, to the point where he openly advocated German trade in China during his tour of Europe in a public lecture he delivered at the Berlin stock exchange. ${ }^{40}$ Despite a certain shift in focus dictated for the most part by the changing situation around him, he had maintained his transnational correspondence network, appearing in Europe as the situation seemed to require it. But although this essay has already revealed a vast communication network with Gützlaff at the centre, its perspective would remain incomplete without a look at Gützlaff's transcultural activities.

Gützlaff's transcultural activities: Between Asia and the »West«

A good starting point for Gützlaff's role in processes of transculturation is his own selfassessment of his linguistic achievements. According to a famous list which he seems to have published several times, his works appeared in a variety of languages: English, German, Dutch and Latin on the European side; Chinese, Japanese, Siamese (or Thai), Laotian, Cambodian and Cochinchinese (Cochinchina being the southern part of Vietnam). ${ }^{41}$ On the Asian side in particular, not all languages carry equal weight: Gützlaff's output in Chinese was by far the most voluminous, including a complete Bible translation, tracts and a number of secular publications. Japanese follows in second place (also including scholarly texts) and Thai comes in third place, whereas in the other languages he »only « produced a translation of the New Testament and/or a dictionary. The list is indicative both of how Gützlaff wanted to be seen by his supporters and of his practical achievements. What it shows most of all is that although the bulk of Gützlaff's work was dedicated to China, his perspective on Asia was as transnational as his view of Europe.

\footnotetext{
${ }^{40}$ Carl GÜTZLAFF, Ueber die Handelsverhältnisse im östlichen Asien. Vortrag, gehalten am 9. Oktober 1850 im Börsen-Saal, Berlin 1850, p. 18.
} 
It is impossible in the context of this essay to examine Gützlaff's writings (both missionary and non-missionary) in detail, and I will not be able to do more than scratch the surface. But the point here is that Gützlaff's transcultural communication, despite his continuing to preach well into the $1840 \mathrm{~s},{ }^{42}$ relied not only on face-to-face interaction. His writings, which included both missionary and secular publications, extended the scope of his impact beyond anything we could refer to meaningfully as a »contact zone«. And Gützlaff’s transcultural mediation worked both ways: from Asia to the »West « and vice versa.

I shall begin with Gützlaff's non-missionary writings in »Western « languages. I have already mentioned his travelogues, historical works and overviews of the China of his day. ${ }^{43}$ These became extremely popular and in the 1840s, even a version of his travelogues specifically targeting children was published in Germany. ${ }^{44}$ Besides, Gützlaff authored a vast range of short texts on the geography, cultures and linguistics of Asia. It appears that the earliest of these texts were published in missionary journals such as the Chinese Repository. It is in this periodical that between 1833 and 1839, Gützlaff's three surveys on the Korean, Japanese and Chinese languages appeared, in which he gave an overview of their structure and writing systems, a subject to which he returned in subsequent publications. ${ }^{45} \mathrm{~A}$ whole series of Gützlaff contributions to the Repository consisted of detailed reviews of Chinese literature, both fictional and non-fictional, about which he was occasionally unforgiving: An early eighteenth-century compilation about gods and spirits was dismissed by Gützlaff as »rubbish «, yet he took interest in a story on the Virgin Mary from the collection. The »Illustrated Description of the Maritime Countries « (Haiguo tuzhi), first published in 1844 by the eminent scholar Wei Yuan (1796-1857) and regarded today as the first global geography in the Chinese language, did not fare much better: Gützlaff scoffed at its »erroneous representations« as well as at a style that »does not rise above mediocrity«, and though he

\footnotetext{
${ }^{42}$ As is evident from Gaïhan's Chinesische Berichte or from the account of the British missionary (later bishop) George SMITH, A Narrative of an Exploratory Visit to Each of the Consular Cities in China and to the Islands of Hong Kong and Chusan, in Behalf of the Church Missionary Society, in the Years 1844, 1845, 1846, London 1847, vol. 2, pp. 64-68.

${ }^{43}$ For a comprehensive list of Gützlaff's publications see Hartmut WALRAVENS, Karl Friedrich Neumann und Karl Friedrich August Gützlaff. Zwei deutsche Chinakundige im 19. Jahrhundert, Wiesbaden 2001, pp. 120-152. ${ }^{44}$ Emil WendT / Theodor VOCKERODE (eds.), Des Missionars Gützlaff Reisen nach den Küstengegenden des Chinesischen Reichs: nebst Auszügen aus vielen andern Reiseberichten, welche Religion, Regierungsverfassung, Volkssitten u.s.w. in China darstellen, für die Jugend bearbeitet, Leipzig 1848.

${ }^{45}$ Reprinted in: KLEIN / ZöLLNER (eds.), Karl Gützlaff und das Christentum in Ostasien, pp. 298-303, pp. 309314.
} 
granted that the work was »not defective in perspicuity«, he still found it »devoid of all interest, except to the very diligent inquirer. « ${ }^{46}$

In the 1840s, when Gützlaff was better known, some of his papers were read at and published by scientific organisations such as the American Philosophical Society, the Royal Geographical Society and the Royal Asiatic Society. ${ }^{47}$ He also corresponded with leading scholars, such as the Prussian explorer Alexander von Humboldt (1769-1859), to whom he confirmed in writing »the puzzling fact that all Chinese as well as Manchus living in China (ca. 370 million people), who, despite being nourished with breast milk, do not know milk, butter and cheese and indeed abhor and disdain all three « ${ }^{48}$ It must be noted, however, that after Gützlaff had dined with Humboldt, the famous geographer judged his missionary guest to be »very amusing but highly ignorant of the geography of Asia outside China. ${ }^{49}$

It is probable that Gützlaff's greatest impact apart from his book-length publications was through more popular magazines such as Das Ausland, to which he either actively contributed or which published digests of his writings. An interesting case is his reception by the German writer Karl May (1842-1912), who was notorious for his plagiarising of scientific and geographical literature. In his novel Der blaurote Methusalem (first serialised in 1888/89 under the title Kong-kheou, das Ehrenwort), May copied a passage by Gützlaff on Chinese junks. Millions of mostly young German readers have read the passage without knowing its true author. ${ }^{50}$ On the whole, however, Gützlaff's most profound impact in Europe and North America was as a populariser of China and especially of Christian missions in China at a very early stage. The buoyant missionary’s optimism coupled with his insistence on the superiority

\footnotetext{
46 All quoted from Hartmut WALRAVENS, Karl Gützlaffs Werke. Bemerkungen zu Rezeption und Wissenstransfer aufgrund der nichtmissionarischen Schriften, in: KLEIN / ZöLLNER (eds.), Karl Gützlaff und das Christentum in Ostasien, pp. 77-103, at pp. 86-87, 94.

${ }^{47}$ Letter from the Rev. Charles Gutzlaff to John Vaughan, Esq., on the Chinese System of Writing, in: Transactions of the American Philosophical Society 7 (1841), pp. 7-9; C. GuTZLAFF, Frontiers of China towards Birmah, in: Journal of the Royal Geographical Society of London 19 (1849), pp. 42-48; C. GUTZLAFF, On the Secret Triad Society of China, Chiefly from Papers Belonging to the Society Found at Hong Kong (1 January 1846), in: Journal of the Royal Asiatic Society of Great Britain and Ireland 8 (1846), pp. 361-367.

${ }^{48}$ Humboldt to Ritter, 12 June 1850, in: Ulrich PässLER (ed.), Alexander von Humboldt - Carl Ritter: Briefwechsel, Berlin 2010, p. 112.

${ }^{49}$ Humboldt to Ritter, after 23 September 1850, in: ibid., p. 117. The same letter also quotes a very unflattering characterisation of Gützlaff by the German minister in London, Karl Josias Bunsen (1791-1860).

${ }^{50}$ Compare Die Chinesischen Dschonken, in: Magazin für die Literatur des Auslandes 6 (1834), pp. 319-320, which is the adaptation of a passage from Gützlaff's Journal of Three Voyages, and Karl MAY, Kong-kheou, das Ehrenwort, Zürich 1991, pp. 93-94. I owe this comparison to WALRAVENS, Karl Gützlaffs Werke, pp. 81-82. See also Erwin KopPen / Bernhard KosciuszKo, Der blau-rote Methusalem, in: Gert Ueding (ed.), Karl-MayHandbuch, Würzburg 2000, pp. 275-279, at p. 275.
} 
of Christianity and European civilisation contributed to an Orientalist attitude that was to dominate relations between China and the »West« for nearly a century.

On the other hand, Gützlaff also targeted Asian audiences. Again, he published secular texts informing a scholarly readership of European societies and culture, e.g. two book-length treatises on Britain in Chinese. Some of these works deliberately adopt the style of Chinese novels, but are equally interspersed with quotations from the Chinese classics. ${ }^{51}$ Between 1833 and 1839, Gützlaff ran a Chinese-language periodical called »The East-West Examiner and Monthly Magazine« (Dong-Xiyang kao mei yue tongjizhuan). In this periodical, he deliberately adopted the language of scholarly Confucianism, stressing the need for friendly relations between China and the »West« - a goal that he sometimes but not always emphasised in his »Western«-language publications. Dong-Xiyang kao meiyue tongjizhuan presented both biblical history (among other things, Gützlaff wrote articles on mankind before and after the Flood) and scientific knowledge. ${ }^{52}$ According to one estimate the news section formed the largest part of the magazine, accounting for about $27 \%$ of its content. Geographical information was the next largest category, forming slightly less than a fifth of the entire output. ${ }^{53}$ Some of the information presented here and in other writings of Gützlaff found its way into the first Chinese world geographies of the 1840s, in particular Wei Yuan's previously mentioned Haiguo tuzhi, first published in 1844 and expanded in 1852, „Four Treatises on the Maritime Countries« (Haiguo si shuo) by Liang Tingnan (1796-1861) of 1844/46 and »A Brief Description of the Maritime Circuit« (Yinghuan zhilüe) by Xu Jiyu (1795-1873), which came out in $1848 .^{54}$ The authors drew the attention of their readership to the importance of Europe as an alternative civilisation. Like their missionary source of information, they focused their attention on Britain and quoted India as a warning example for China (Gützlaff had written about India as a »tributary state« of Britain). In the political and intellectual climate of the 1850s, their publications did not win them many friends; and it was

\footnotetext{
${ }^{51}$ HANAN, The Missionary Novels, pp. 423-424.

${ }^{52}$ A modern edition is: HuANG Shijian (ed.), Dong-Xiyang mei yue tongjizhuan, Beijing 1997; for an analysis see ZHENG Lian'gen, Naxie huoyue zai jindai Zhongguo de xiyang chuanjiaoshi, Taipei 2011, pp. 155-156; LUTZ, Opening China, pp. 182-199.

53 LIEN Hui-chu, »Dong-Xiyang mei yue tongjizhuan« zhong ditu yishi yu dilixue chuanbo yanjiu, 〈http://research.ctu.edu.tw/vra/resources/100/17100/B01/408/5/f8ed86eb37fd5f9a01382e7213aa003e.pdf〉, pp. 1-10, at p. 2 (access date 2 October 2014). ${ }^{54}$ Ibid.
} 
only in the 1860s, when China had accepted its subordination under the treaty regime (and hence »Western « imperialism) as a matter of fact that they were reappraised. ${ }^{55}$

It was as a translator that Gützlaff had the greatest impact in China, and of course one should not underestimate the impact of power relations on translation. In order to understand his contribution, let us first look at a contrasting example: Gützlaff's translation of the Gospel of John, the first ever Protestant Bible translation into Japanese. It was compiled with the help of three of the seven Japanese castaways whom Gützlaff had in vain tried to repatriate, all of them fishermen from Owari. The manuscript was sent off to the printer in Singapore before Gützlaff set out for Japan on board the Morrison, but Gützlaff only received it after his return from his unsuccessful mission. ${ }^{56}$ According to the careful analysis by the linguist Yōko Nishina, the text deviates strongly from the standard for written Japanese, both in terms of vocabulary and grammar. It is strongly influenced by the Owari dialect and, most conspicuously, it is written in Katakana (a syllabary), as Gützlaff's collaborators did not know Chinese characters (called kanji in Japanese). Later versions abandoned the latter shortcoming, as a synoptic overview of early translations shows. With all its defects, Gützlaff's Japanese Gospel of John provides an interesting perspective on how important indigenous collaboration is for missionary translation projects. Gützlaff had clearly overestimated his proficiency in Japanese.

We do not know a lot about Gützlaff's Chinese collaborators, but gifted linguist that he was (his difficulties with Japanese notwithstanding), he immersed himself deeply into Chinese and his translations into that language may safely be said to have had a far greater impact. Gützlaff began a Bible translation in 1834, collaborating with his erstwhile mentor, the British missionary Walter Henry Medhurst (1796-1857), who had been instrumental in refocusing his attention on China in the late 1820s. Medhurst quit the project in 1836 but his Prussian colleague persevered and a first complete translation appeared in 1838, though Gützlaff continued revising it till 1845. ${ }^{57}$ Historically, the Gützlaff-Medhurst Bible first attained importance as the version used by the Taiping movement (1851-1864) - a rebellion against

\footnotetext{
${ }^{55}$ Bernd EBERsteIn, Hamburg - China. Geschichte einer Partnerschaft, Hamburg 1988, pp. 141-146; LUTZ, Opening China, pp. 202-214. Wei's and Xu's works incorporate material from an unpublished work by Lin Zexu, »Account of the Four Continents` (Si zhou zhi).

${ }^{56}$ Yōko NiSHINA, Gützlaffs japanisches Johannesevangelium, in: KLEIN / ZöLLNER (eds.), Karl Gützlaff und das Christentum in Ostasien, pp. 173-192, at pp. 173-175.

${ }^{57}$ Zetzsche, Gützlaffs Bedeutung für die protestantischen Bibelübersetzungen ins Chinesische, in: KLEIN / ZÖLLNER (eds.), Karl Gützlaff und das Christentum in Ostasien, pp. 155-171, at pp. 158-164.
} 
the Imperial Qing dynasty based on the »folk-religionization of Christianity«, as it has been called. ${ }^{58}$ This connection was rather accidental: The founder of the movement, Hong Xiuquan (1814-1864), who claimed to be the younger brother of Jesus Christ, had been given a copy of the Gützlaff-Medhurst translation. Other effects only became visible in the long run: Theologically by far the most important was the rendering of God as Shangdi (an ancient term for the deified ancestor of the ruler) and of the Greek $\lambda o \delta o \varsigma$ as dao, a classical philosophical term used by Confucians, Daoists and Buddhists alike. Some transliterations proposed by Gützlaff have found their way into everyday usage, such as youtairen for Jews and Yiselie for Israel. ${ }^{59}$ But the greatest cultural curiosity comes from one of Gützlaff's nonreligious texts, a geographical compendium called »Illustrated geography of the myriad countries« (Wan guo dili quan ji), probably composed in 1842-1843. Much like Gützlaff’s Bible translation, this introduced quite a few terms that stuck, most notably transliterations of geographical names. ${ }^{60}$ Arguably the most conspicuous of these is the name Gützlaff chose for the city of Hamburg, Hanbao - a rather counterintuitive term for Chinese, as it means »Han Castle« or »Chinese Castle«. Via Wei Yuan and his Haiguo tuzhi (which still uses three other versions for the same city), the name entered the Chinese lexicon. Indirectly, Gützlaff is also responsible of the Chinese word for the Hamburger, called »Hamburg wrap« (Hanbao bao) in Chinese. ${ }^{61}$ Nothing could provide a stronger testimony to the lasting impact of Gützlaff's transcultural activities than this.

\section{Conclusion}

Karl Gützlaff's diverse activities at the intersection of cultures were embedded in multifarious communication flows. Both his active involvement with British imperialism and his evangelising depended on his presence on the spot. In this sense, not only was he operating within the contact zone, he was also a product of the contact zone. Only by situating himself at the boundary of Chinese and »Western« cultures - and here, for once, I am referring to the contact zone as a tangible space - could he develop the transcultural persona he eventually adopted and which combined the copresence, however hierarchical and uneven, of various

\footnotetext{
${ }_{-58}^{58}$ LIU Ying-hua, The Folk-religionization of Christianity in China - Hong Xiuquan's Yuandao jueshi xun and the Taiping Rebellion, in: WANG Chengmian (ed.), Shizijia qian de sisuo - wenben jiedu yu jingdian quanshi, Taipei 2010, pp. 77-106. For the impact of the Gützlaff translation on the Taiping see ZETZsCHE, Gützlaffs Bedeutung, pp. 170-171.

${ }_{-59}^{50}$ ZETZSCHE, Gützlaffs Bedeutung, pp. 167-170.

$-{ }^{60}$ ZHUANG Qinyong, Guo Shilie »Wan guo dili quanji« faxian yu yiyi, in: Journal of the History of Christianity in China 7 (2006/07), pp. 1-18.

${ }^{61}$ EBERSTEIN, Hamburg - China, pp. 150-152.
} 
cultural strands of East Asia and the »West«. It was this persona which enabled him to speak and write, with the authority of a culturally competent intermediary, on things Chinese, or more broadly East Asian, in the »West« and, conversely, on things »Western« in China and more generally East Asia. This did not preclude caused by Gützlaff's obvious capacity for self-aggrandisement, his personal ambition or overestimation of his capabilities.

But it would be a gross injustice to Gützlaff to understand him merely as a figure of the contact zone, because to do so would mean to overlook the many ways in which the liminal space within which he operated was connected with the world at large. As an independent missionary, Gützlaff could only sustain his work by building up a supporting network in Europe and the United States. This network had to be cultivated by way of regular transmission of information. This is most obvious in the 1830s, but even after Gützlaff had moved toward a greater institutionalisation of his home base in the mid-1840s, keeping his supporters informed was of the essence. That Gützlaff felt his personal presence was required in Europe in 1850 further attests to this, as does his careful handling of local media during his Grand Tour.

Besides, Gützlaff’s cultural mediation between East Asia and the »West « far exceeds the notion of a contact zone in a limited and geographic sense. Gützlaff digested information from the »West « and transmitted it to China and vice versa. In so doing, he relied on a global infrastructure of communication - letters that could reach their addressees with certainty and within reasonable time, scholarly publications that could be read at learned societies' meetings and published in their periodicals. Much of the impact he created was not so much down to his own writings but rather through indirect forms of transmission, as in the case of the first Chinese geographers. This was a »copresence« in an extended sense, one that stretched across space and - again most obviously in the case of the Chinese geographers also across time. Applying the concept of a »contact zone« alone is insufficient to capture it. The lessons of Gützlaff and his communications network are twofold: Firstly, the contact zone cannot be studied in isolation; it must be analysed in its connections with global communication flows. Secondly, the case of Gützlaff points to the role of individual human agency within such flows. 